\title{
ANALISIS ETIKA KOMUNIKASI SISWA MELALUI PENDIDIKAN KARAKTER ISLAM DI SMA KOTA TANGERANG SELATAN
}

\author{
Junaidi *)
}

\begin{abstract}
This study aims at analyzing the factors affecting students to speak dirty words as an improper action in communication and understanding Islamic Character Building approach to solve their communication ethics. In addition, the study also describes the influence of environment, school and society in their roles on their communication ethics. The populations in this study are all high school students, approximately 10.092 students, in Southern Tangerang using purposive sampling which determines the subjects in the study according to the requirement of data representation to obtain depth of knowledge. The number of samples in this study is $2.5 \%$ of the whole population, approximately 252 subjects which are equally distributed on the 12 schools being observed. In this regard, each school represents 21 subjects. Meanwhile, the study applies observation, interviews and documentation to collect the research data. In addition, it uses Domain Analysis, Taxonomy Analysis, Componential Analysis and Analysis of Cultural Themes to process the data. As the result, the frequency of speaking bad words in the study shows $98 \%$ of respondents (247 respondents) stated "frequently", $1.6 \%$ (4 respondents) said "sometimes" and only $0.4 \%$ (1 respondent) answered "never". Regarding the dirty words spoken, the study obtains list of words consisting of names of animals such as monkey, dogs or pig, names of sexual organs and terms such as dick or fuck and so on. In addition, it indicates that the partners in the communication are peers, siblings or things that stimulate angers. Meanwhile, the reactions displayed by the partners in the communication vary, such as acting normal, showing anger, laughing or ignoring. At last, the study results in the factors affecting the students to speak dirty words are spontaneity, joke, anger, habits, irritability, response to a mock and environment influence.
\end{abstract} Keywords: Communication Ethics, Character Building, Domain Analysis,
Taxonomy Analysis, Analysis Componential.

\section{PENDAHULUAN}

Setiap orang menyadari bahwa harapan di masa yang akan datang terletak pada putra-putrinya. Hampir setiap orang berkeinginan agar putra-putrinya kelak menjadi orang yang berguna. Oleh karena itu perlu adanya pembinaan yang terarah bagi putra-putrinya sebagai generasi penerus bangsa sehingga mereka dapat memenuhi harapan yang dicita-citakan.

Berbicara mengenai kenakalan siswa merupakan masalah yang dirasakan 
sangatlah penting dan menarik untuk dibahas karena siswa merupakan bagian dari generasi muda. Mereka adalah aset nasional dan merupakan tumpuan harapan bagi masa depan bangsa dan negara serta agama. Untuk mewujudkannya maka sudah tentu menjadi kewajiban dan tugas kita semua, baik orang tua, guru dan pemerintah. Untuk mempersiapkan generasi muda menjadi generasi yang tangguh dan berwawasan/berpengetahuan yang luas, yaitu dengan jalan membimbing dan mengarahkan mereka semua sehingga menjadi warga negara yang baik dan bertanggung jawab secara moral. Berkaitan dengan hal ini maka Surakhmad (1997:12-13) menyatakan: "Adalah suatu fakta di dalam sejarah pembangunan umat yang akan memelihara kelangsungan hidupnya untuk senantiasa menyerahkan dan mempercayakan hidupnya didalam tangan generasi yang lebih muda itulah yang kemudian memikul tanggung jawab untuk memelihara kelangsungan hidup umatnya, tetapi juga meningkatkan harkat hidup tersebut. Apabila generasi muda yang seharusnya menerima tugas penelitian sejarah bangsanya tidak memiliki kesiapan dan kemampuan yang diperlukan oleh kehidupan bangsa itu, niscaya berlangsung ke arah kegersangan menuju kepada kekerdilan dan akhirnya sampai pada kehancuran. Oleh karena itu, kedudukan generasi muda dalam suatu masyarakat sangat vital".

Menurut Undang-undang Nomor 20 tahun 2003 tentang Sistem Pendidikan pada Pasal 3, yang berbunyi pendidikan nasional berfungsi mengembangkan kemampuan dan membentuk karakter serta peradaban bangsa yang bermartabat dalam rangka mencerdaskan kehidupan bangsa. Pendidikan nasional bertujuan untuk berkembangnya potensi peserta didik agar menjadi manusia yang beriman dan bertakwa kepada Tuhan Yang Maha Esa, berakhlak mulia, sehat, berilmu, cakap, kreatif, mandiri, dan menjadi warga negara yang demokratis, serta bertanggung jawab (Aqib dan Sujak, 2011:2).

Menurut Daradjat, (1998:2) ada beberapa faktor penyebab terjadinya kenakalan siswa antara lain: Pertama, Kurang pendidikan. Kedua, Kurang pengertian orang tua tentang pendidikan. Ketiga, Kurang teraturnya pengisian waktu. Keempat, Tidak stabilnya keadaan sosial, politik dan ekonomi. Kelima, Banyaknya film, dan buku-buku bacaan yang tidak baik. Keenam, Merosotnya moral dan mental orang dewasa. Ketujuh, Pendidikan dalam sekolah yang kurang baik. Kedelapan, 
Kurangnya perhatian masyarakat dalam pendidikan anak.

Bentuk-bentuk kenakalan siswa itu berbeda-beda. Yang paling sering dijumpai dan akan menjadi inti dari penelitian ini, yaitu fenomena komunikasi siswa dengan menggunakan kata-kata tidak baik, tetapi menurut siswa itu kata-kata gaul, seperti: kata bego, tolol, idih najis dan lain-lain. Tindakan tersebut tentunya tidak merefleksikan seorang muslim yang dalam agamanya diperintahkan untuk bertutur kata yang baik. Allah berfirman dalam (QS. AnNisaa:8).

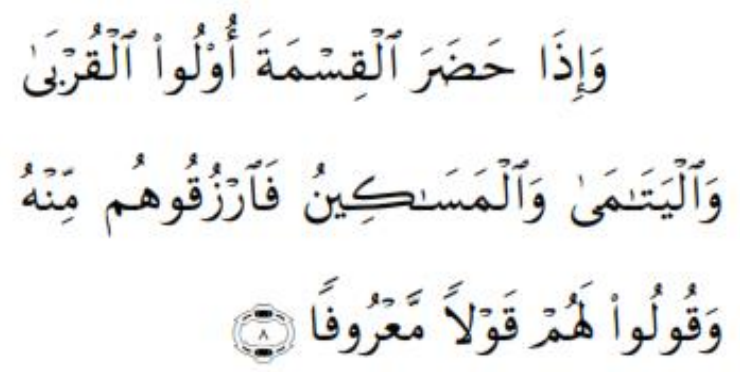

Artinya:"Dan apabila sewaktu pembagian itu hadir kerabat, anak yatim dan orang miskin, Maka berilah mereka dari harta itu (sekedarnya) dan ucapkanlah kepada mereka Perkataan yang baik”. (Alquran Surat An-Nisaa ayat 8).

Untuk mengatisipasi hal-hal tersebut maka hal utama yang juga perlu diperhatikan terhadap generasi muda adalah adanya penghayatan terhadap nilai-nilai PAI. Usaha ini memiliki nilai baku yang tidak dapat dikesampingkan, terutama pada proses belajar mengajar dalam sistem pendidikan formal antara pendidik (guru) dan si terdidik (siswa) akan banyak saling mendukung dan menunjang proses penghayatan terhadap nilai-nilai PAI (akhlak) tersebut. Namun, dalam hal ini, orang tua mempunyai peran yang tidak kalah pentingnya dengan guru di sekolah. Hal ini dikarenakan orang tua juga mem- berikan contoh atau suri teladan yang baik secara langsung, terutama yang berhu- bungan dengan nilai-nilai akhlak di atas.

Selain itu peranan masyarakat sebagai lingkungan pendidikan yang ketiga setelah keluarga dan sekolah juga memiliki tanggung jawab terhadap generasi muda (anak-anak remaja). Masyarakat ikut serta mengontrol dan melindungi mereka dari tindakan yang dapat merusak nilai-nilai luhur agama. Masyarakat perlu mengetahui aspek pokok yang terkandung di dalam agama serta norma-norma hukum yang tumbuh dan berkembang dalam masyarakat, baik yang tertulis maupun yang tidak tertulis.

Dalam artikel ini akan dibahas factorfaktor yang mendorong siswa untuk berkatakata kotor, tidak mengindahkan etika komunikasi, dan mengulas pendekatan character building Islam sebagai sebuah solusi untuk menanganani etika komunikasi 
tersebut. Selanjutnya, dalam artikel ini juga akan dianalisis pengaruh lingkungan rumah, sekolah, dan masyarakat terhadap etika komunikasi siswa.

\section{METODOLOGI PENELITIAN}

Subjek atau populasi dalam penelitian ini adalah siswa-siswi Sekolah Menengah Atas (SMA) yang berlokasi di Tangerang Selatan dengan total jumlah siswa sebanyak 10.092 siswa. Adapun teknik sampling yang digunakan adalah teknik Purposive Sampling. Siswa akan dimasukkan sebagai sampel dengan kriteria data/konsultasi dengan guru BP, yang sebagian siswa termasuk kategori "bermasalah" dan sebagiannya "tidak bermasalah".

Dalam pengumpulan data dilakukan dengan teknik observasi langsung, Selanjutnya dalam penelitian ini juga diaplikasikan wawancara yang dilakukan secara terbuka. Dalam penelitian ini tidak digunakan pedoman wawancara yang telah tersusun secara sistematis dan lengkap. Pedoman wawancara yang digunakan hanya berupa garis-garis besar permasalahan yang akan ditanyakan. Dalam studi ini juga dilakukan dokumentasi terhadap data-data dan arsip-arsip sekolah.

Setelah data didapat selanjutnya dilakukan analisis data dengan 4 langkah: (a) Analisis Domain (Domain Analysis), dilakukan untuk mendapatkan gambaran yang umum dan menyeluruh tentang situasi sosial yang diteliti untuk menentukan domain-domain atau kategorisasi hasil analisis. Domain disajikan dalam tabel analisis domain. (b) Analisis Taksonomi (Taxonomic Analysis), adalah analisis terhadap keseluruhan data berdasarkan domain yang telah ditetapkan. Hasil analisis domain disajikan dalam bentuk diagram outline. (c) Analisis Komponensial (Componential Analysis), yaitu mencari data yang spesifik dan kontras melalui observasi, wawancara dan dokumentasi yang terseleksi. Data yang spesifik dan kontras ditemukan melalui wawancara kepada beberapa subjek serta studi dokumentasi terfokus dan terseleksi. (d) Analisis Tema Kultural (Discivering cultural Analysis), yaitu mencari hubungan antara domain dan bagaimana hubungan dengan keseluruhan dan selanjutnya dinyatakan kedalam bentuk judul penelitian.

Analisis data dalam penelitian ini juga akan dilakukan dengan penyusunan data, yakni penyususnan kata-kata hasil wawancara hasil observasi, dan dokumendokumen berdasarkan kategorisasi yang sesuai dengan masalah penelitian. Selanjutnya, berdasarkan data yang akan 
diperoleh, dikembangkan pinjaman data melalui pencarian data selanjutnya. Dalam penelitan ini, akan dicatat data apa adanya tanpa intervensi dari teori yang terbaca atau paradigma peneliti yang selama ini dimiliki. Situasi wajar apa adanya dijadikan bahan penelitian yang dimasuki peneliti tanpa intervensi situasi. Peneliti berusaha mencari makna inti dari kelakuan dan perbuatan yang terlihat. Hal ini dilakukan dalam rangka memahami perilaku tersebut dalam konteks pikiran. Pada saat wawancara dilakukan analisis terhadap jawaban yang diwawancarai. Apabila jawaban sumber data belum memuaskan, akan dilanjutkan ke pertanyaan lagi sampai data dianggap kredibel. Aktivitas dalam analisis data dilakukan secara interaktif dan berlangsung secara terus menerus sampai tuntas.

\section{HASIL DAN PEMBAHASAN}

\section{Frekuensi Tindak Tutur Siswa}

Penelitian ini didasarkan pada informasi yang didapatkan dari wawancara dengan responden yang berjumlah 252 siswa Sekolah Menengah Atas (SMA). Para siswa berasal dari 12 sekolah. Masalah yang diteliti berkenaan dengan frekuensi peristiwa tindak tutur siswa dengan menggunakan kata-kata komunikasi yang kurang menyenangkan (tidak beretika). Hasil data wawancara menunjukkan bahwa $98 \%$ responden (sekitar 247 responden) menyatakan bahwa mereka sering mengucapkan tindak tutur (kata-kata) kotor. Selanjutnya, 1,6\% (4 responden) menyatakan kadangkadang mengucapkan kata-kata kotor. Dari jumlah responden yang cukup banyak tersebut, hanya $0,4 \%$ (1 responden) yang menjawab bahwa dia tidak pernah menggunakan kata kotor dalam komunikasinya dengan orang lain. Berikut ini disajikan data dalam bentuk tabel.

Tabel 1: Frekuensi Peristiwa Tindak Tutur Siswa yang Kurang Sopan Sebagai Pembicara

\begin{tabular}{|c|c|c|c|}
\hline No & Kategori & $\begin{array}{c}\text { Jumlah } \\
\text { Responden }\end{array}$ & Prosentase \\
\hline $\mathbf{1}$ & $\begin{array}{c}\text { Tidak } \\
\text { Pernah }\end{array}$ & 1 & $0,4 \%$ \\
\hline $\mathbf{2}$ & $\begin{array}{c}\text { Kadang- } \\
\text { Kadang }\end{array}$ & 4 & $1,6 \%$ \\
\hline $\mathbf{3}$ & Sering & 247 & $98 \%$ \\
\hline $\begin{array}{c}\text { Jum- } \\
\text { lah }\end{array}$ & & $\mathbf{2 5 2}$ & $\mathbf{1 0 0 \%}$ \\
\hline
\end{tabular}

Untuk mendukung akurasi hasil data pada poin frekuensi peristiwa tidak tutur ini, peneliti tidak hanya memberikan instrumen wawancara yang mengarahkan kepada informasi responden sebagai pihak pertama dalam komunikasi (pembicara), tetapi juga pada instrumen wawancara lainnya. Peneliti juga menggali informasi apakah responden tersebut pernah mendengarkan pihak-pihak, dalam hal ini siswa-siswa lain sebagai 
teman-teman mereka, yang melakukan tidak tutur tidak sopan. Dari hasil wawancara pada instrumen ini didapatkan bahwa $57 \%$ responden yang berjumlah 143 orang menyatakan bahwa mereka pernah mendengarkan teman-temannya melakukan tindak tutur yang kurang sopan, baik mereka sebagai lawan bicara ataupun pihak ketiga. Selain itu, $42 \%$ responden dengan jumlah 107 orang menyatakan bahwa mereka sering mendengarkan kata-kata kotor yang dilontarkan oleh temen-teman mereka baik sebagai lawan bicara ataupun orang ketiga. Dari sejumlah persentase tersebut, hanya $1 \%$ responden, yaitu 2 orang yang memberikan pernyataan bahwa mereka jarang mendengarkan teman-temannya berkata kotor. Untuk mempermudah hasil tersebut, berikut dideskripsikan hasil data dalam bentuk tabel.

Tabel 2 Frekuensi Peristiwa Tindak Tutur Siswa yang Kurang Sopan Sebagai Pihak Kedua (Lawan Bicara) atau Ketiga

\begin{tabular}{|c|c|c|c|}
\hline No & Kategori & $\begin{array}{r}\text { Jumlah } \\
\text { Responden }\end{array}$ & Prosentase \\
\hline $\mathbf{1}$ & Pernah & 143 & $57 \%$ \\
\hline $\mathbf{2}$ & Sering & 107 & $42 \%$ \\
\hline $\mathbf{3}$ & Jarang & 2 & $1 \%$ \\
\hline Jmlh & & $\mathbf{2 5 2}$ & $\mathbf{1 0 0 \%}$ \\
\hline
\end{tabular}

Dari hasil data di atas, dapat dibuat simpulan bahwa etika berkomunikasi di antara para siswa perlu adanya arahan baik dalam bentuk kegiatan konseling, seperti pelatihan-pelatihan komunikasi maupun pelatihan-pelatihan penggunaan bahasa baku. Selain itu perlu adanya kegiatankegiatan keagamaan yang dapat mengarahkan siswa pada adanya tindak positif, terutama dalam hal bertutur kata yang baik.

Konseling mempunyai peran signifikan dalam membantu siswa untuk mencapai keberhasilan dan mampu untuk beradaptasi dalam situasi hidup apapun. Hal ini selaras dengan yang dinyatakan oleh Winkles bahwa bimbingan konseling di sekolah bertujuan untuk membantu siswa menghadapi semua perkembangan hidup secara sadar dan bebas, hingga ia mampu membuat pilihan secara bijaksana serta mampu menyesuaikan diri. Hal senada juga dikemukakan oleh Prayitno dan Erman Amti (2004:114) bahwa tujuan umum BK adalah membantu individu untuk menjadi insan yang berguna dalam kehidupannya, memiliki berbagai wawasan, pandangan, interpretasi, pilihan, penyesuaian dan keterampilan yang tepat sesuai dengan dirinya dan lingkungannya. Dengan demikian, jelaslah kiranya bahwa bimbingan konseling yang ada di masing-masing instansi pendidikan perlu dioptimalkan. Hal ini dilakukan agar dapat berfungsi mengatasi 
etika komunikasi, khususnya di kalangan siswa SMA.

Jelas kiranya bahwa bimbingan dan konseling merupakan salah satu komponen dari pendidikan kita. Bimbingan dan konseling merupakan suatu kegiatan bantuan dan tuntunan yang diberikan kepada individu pada umumnya, dan siswa pada khususnya di sekolah dalam rangka meningkatkan mutunya. Hal ini sangat relevan jika dilihat dari perumusan bahwa pendidikan itu merupakan usaha sadar yang bertujuan untuk mengembangkan kepribadian dan potensi-potensinya (bakat, minat dan kemampuan). Kepribadian masyarakat menyangkut masalah perilaku atau sikap mental dan kemampuannya meliputi masalah akademik dan keterampilan.

Dengan kata lain, bimbingan merupakan bantuan khusus yang diberikan kepada anak didik dengan memerhatikan kemungkinan-kemungkinan dan kenyataankenyataan tentang adanya kesulitan yang dihadapinya. Bimbingan perlu dilakukan dalam rangka perkembangan yang optimal sehingga mereka dapat memahami diri dan bertindak serta bersikap sesuai dengan tuntutan dan keadaan lingkungan sekolah, keluarga, dan masyarakat. Pada akhirnya, dengan adanya implementasi bimbingan konseling tersebut tercipta generasi-generasi yang menjanjikan.

Dalam penelitian ini, selain siswa, guru juga menjadi responden penelitian. Berdasarkan hasil wawancara dengan 12 guru mengenai frekuensi tindak tutur kotor siswa, $100 \%$ responden mengatakan bahwa mereka pernah mendengar siswanya mengucapkan kata-kata yang tidak layak diucapkan. Hasil ini memperkuat bahwa fenomena komunikasi yang tidak beretika benar-benar terjadi di kalangan siswa SMA di Tangerang Selatan.

\section{Bentuk Kata-Kata Tutur Siswa}

Mengenai bentuk kata-kata kotor yang diucapkan oleh siswa, responden tidak hanya diteliti dari sisi mereka sebagai pihak pertama (pembicara), tetapi juga sebagai pihak kedua (lawan bicara). Data ini akan menunjukkan kata-kata kurang sopan apa saja yang sering responden ucapkan atau responden dengarkan.

Pada poin pertama, yakni responden sebagai pembicara, data hasil wawancara menyebutkan bahwa kata-kata kotor yang diucapkan sangatlah bervariasi, dari namanama binatang, seperti monyet, kucing, tikus, anjing, babi, kampret atau qirdun (istilah lain dari monyet), asu (bahasa Jawa yang berarti anjing), dan anjing atau anjir 
(transformasi kata dari kata anjing). Selain itu, terdapat juga kata-kata yang berkaitan dengan organ tubuh dan istilah-istilah seksual, seperti itil, tete, toket, (organ di sekitar dada perempuan), fuck/ngentot, ngewe (berhubungan badan), kontol/titit (organ vital laki-laki), peler (testis), vaginal memek (organ vital perempuan), asshole (anus), dan jablay/perek/pecun/bitch/cabecabean/lonte yang berarti seorang pelacur.

Selanjutnya, variasi kata kotor yang responden juga seringkali katakan berhubungan dengan keadaan mental atau intelektual, seperti bego, tolol, goblok, dongo, oon, PA, bloon, pengo atau dodol yang mempunyai arti dan bahasa kasar dari kata bodoh, dan idiot, miring atau sinting yang berarti gila. Selain itu, juga didapatkan kata-kata yang berhubungan dengan kotoran seperti tai, shit atau, ee yang berarti kotoran manusia atau hewan, bangke (bangkai), najis, dan sampah. Tabel berikut akan menggambarkan frekuensi kata-kata apa saja yang bermunculan di kalangan responden dalam hal ini di kalangan siswa Sekolah Menengah Atas yang dihitung dan digabungkan dari hasil wawancara dengan mereka.

Di samping itu, berdasarkan hasil wawancara dengan para guru yang menjadi subjek dalam penelitian ini mengenai kata- kata kurang layak diucapkan oleh siswa. Jawaban yang diberikan oleh guru-guru sangat singkat namun tidak berbeda dengan jawaban yang diberikan oleh para siswa, yang mana kata tersebut berkisar pada nama nama binatang seperti anjing atau monyet, hal-hal yang berkaitan dengan keadaan intelektual seseorang seperti bego, tolol, PA, oon, sok pintar, dan hal-hal yang berhubungan dengan tindak tanduk sesorang seperti brengsek, sialan, kurang ajar. Selain itu, ada salah seorang guru yang menyatakan salah satu kata kotor yang diucapkan siswa adalah berkaitan dengan kotoran seperti tai (kotoran manusia atau binatang).

\section{Lawan Bicara Tindak Tutur Siswa}

Mengenai siapa saja lawan bicara responden dalam berkomunikasi, dengan menuturkan kata-kata yang kurang sopan, berikut penjelasannya. Berdasarkan hasil wawancara, semua responden menjawab bahwa lawan bicara yang seringkali menjadi object dalam tutur kata yang kurang sopan tersebut adalah teman bahkan sahabat dekat. Namun, selain menyebutkan teman sebagai lawan bicara, beberapa responden juga menjawab saudara kandung baik adik atau kakak, kerabat seperti sepupu, orang lain, baik dikenal maupun tidak dikenal yang membuat kesal, jengkel atau emosi, musuh, 
bahkan terhadap orang tua, guru, dan tokoh masyarakat. Selain itu, terkadang yang menjadi lawan bicara dari kata-kata kotor tersebut adalah diri sendiri atau barangbarang seperti koneksi internet, komputer, tugas sekolah atau nilai sekolah yang tidak memuaskan. Dalam tabel berikut ini akan digambarkan hasil jawaban wawancara para responden.

\section{Reaksi Terhadap Tindak Tutur Siswa}

Berbicara mengenai reaksi, yang dalam hal ini dapat diartikan sebagai respon terhadap suatu hal, berdasarkan hasil wawancara diperoleh gambaran bahwa siswa mempunyai reaksi yang berbeda-beda dalam menanggapi kata-kata kotor yang dilontarkan oleh lawan bicaranya. Pada bagian ini, akan dibahas hasil jawaban wawancara responden sebagai pihak pertama, yang melontarkan kata-kata kotor terhadap lawan bicaranya. Dengan kata lain, mereka akan dijadikan sebagai sumber data untuk menggambarkan bagaimana reaksi lawan bicaranya mendapati dirinya dilontari kata-kata kotor. Dari 252 responden, 155 responden menyatakan bahwa lawan bicara mereka bereaksi biasa biasa saja. Dalam hal ini dapat diartikan bahwa mereka tidak terlalu bermasalah ketika teman mereka melontarkan kata-kata kurang baik.
Selanjutnya, 88 responden dari keseluruhan 252 responden menyebutkan bahwa lawan bicara mereka membalas dengan kata-kata kotor juga. Selain itu, 78 responden dari 252 responden mengekspresikan reaksi mereka dengan cara marah, kesal, emosi dan jengkel terhadap lawan bicaranya.

Reaksi lain yang dieskpresikan, sekitar 70 responden dari keseluruhan responden berpendapat lawan bicara mereka justru tertawa ketika dilontarkan kata-kata jorok. Dalam hal ini, dapat dianalisis bahwa mereka senang ketika mendapatkan dirinya dilontari kata-kata kotor. Dari 252 responden, 36 responden hanya bereaksi diam atau cuek ketika mendapati dirinya dilontari kata-kata kotor. Di samping itu, terdapat 4 responden dari keseluruhan 252 responden yang melakukan tindak fisik sebagai reaksi terhadap lawan bicaranya yang berkata kotor. Dari wawancara berkenaan dengan reaksi ini, didapatkan hal yang menarik dari masing-masing 1 responden dari 252 responden, masingmasing dari mereka menyatakan bahwa lawan bicara mereka merenung akan apa yang telah dia perbuat sehingga temannya berkata-kata kotor. Ada pula yang mengucapkan kalimat istighfar ketika mendengar teman-temannya melontarkan kata kotor terhadap dirinya, bahkan ada juga 
yang memberanikan diri untuk menasihati lawan bicaranya. Ketiga reaksi terakhir tersebut bisa menjadi sebuah hal yang perlu diterapkan di kalangan siswa untuk saling mengingatkan satu sama lain. Pada akhirnya penanaman karakter untuk saling menasihati dalam kebenaran (al-haqq) dan ketakwaan (at-taqwa) dapatlah terwujud di kalangan mereka sebagai penerus bangsa.

Dalam poin reaksi ini, juga diwawancari responden sebagai pihak ketiga sehingga didapatkan juga informasi dari mereka yang tidak hanya sebagai pembicara, tetapi juga sumber untuk menjelaskan bagaimana respon pihak-pihak yang mereka lihat ketika dilontari kata-kata kotor. Hasil wawancara menunjukkan kategori reaksi dalam poin ini tidak jauh berbeda dengan hasil di atas. Hanya jumlah dan persentasenya saja yang berbeda. Pada reaksi merenung, mengucapkan istighfar, dan menasihati tidak ada dalam hasil wawancara ini. Selain itu, terdapat satu reaksi lain, yakni tersenyum.

Dari gambaran di atas dapat ditemukan adanya tindakan umum yang biasanya dilakukan siswa dalam menanggapi apa yang terjadi terhadap mereka. Dengan melihat jawaban tersebut, dapatlah dilihat kurangnnya penanaman karakter seperti sabar, mawas diri, atau tanggung jawab terhadap apa yang mereka lakukan.

Karakter terpenting yang perlu ditanamkan berdasarkan gambaran hasil wawancara tersebut, yaitu sabar. Menurut Qardawi, (1990:39) dalam Alquran terdapat banyak aspek kesabaran, antara lain sabar terhadap petaka dunia, sebagaimana firman Allah dalam surat Al-Baqarah ayat 155 157:
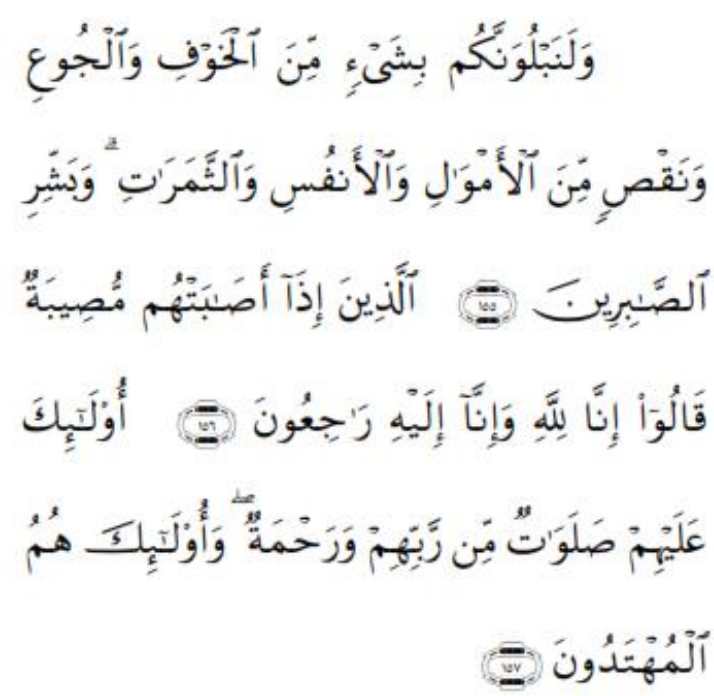

Artinya: "Dan sungguh akan Kami berikan cobaan kepadamu, dengan sedikit ketakutan, kelaparan, kekurangan harta, jiwa, dan buah-buahan. Dan berikanlah berita gembira kepada orang-orang yang sabar, (yaitu) orang-orang yang apabila ditimpa musibah, mereka mengucapkan, "Inna lillahi wa inna ilaihi raji'un." Mereka itulah yang mendapatkan keberkatan yang sempurna dan rahmat dari Rabbnya, dan 
mereka itulah orang-orang yang mendapat petunjuk". (Q.S. Al-Baqarah: 155-157).

Secara tidak langsung ayat di atas dapat dikaitkan dengan keadaan siswa yang tidak bisa menahan emosi ketika sesuatu menimpanya sehingga keluarlah kata-kata yang tidak pantas diucapkan oleh seorang muslim sejati. Dengan demikian, siswa perlu mengetahui dan mengaplikasikan pentingnya sifat sabar. Menurut Shihab (2000:337-339) orang yang sabar akan tahu siapa dirinya. Dengan kesabaran maka seseorang dapat menarik hikmah setiap peristiwa yang menyenangkan atau menyakitkan. Orang yang sabar akan mampu menerjemahkan setiap apa yang dia alami. Mengenal diri tanpa kesabaran tidak akan berhasil dengan baik. Hanya dengan sabar semua peristiwa dapat dilewati sesuai dengan rida Allah. Selain itu, Shihab berpendapat bahwa orang yang sabar akan dapat memahami perkembangan dan pertumbuhan dirinya. Dengan sabar maka seseorang akan dapat mengetahui kebaikan dan keburukan apa saja yang ia lakukan selama hidupnya. Apakah ketaatan dalam beribadah sudah baik dan apakah kemampuan menahan diri dari maksiat sudah baik.

Jika dikaitkan pendapat M. Quraish Shihab di atas dengan fenomena yang terjadi di kalangan siswa, ternyata masih banyak siswa-siswa sebagai generasi kita tidak sabar dalam menghadapi kesulitan dan problematika yang dihadapi. Hal ini salah satunya dibuktikan dengan kemampuan mereka dalam berkomunikasi dengan lingkungannya. Seringkali didapatkan mereka berkatakata kotor dalam komunikasi sehari-hari. Dengan demikian, mereka perlu melatih diri untuk terus berusaha menjadi pribadi yang positif.

Dari sini, perlu disadari bahwa sabar memiliki peranan yang sangat besar dalam menjaga keimanan seorang hamba. Baik sabar dalam menghadapi musibah, sabar dalam menjalankan ketaatan, maupun sabar dalam menjauhi maksiat.

Selain melatih kesabaran, siswa juga harus mengetahui bagaimana cara mengendalikan emosinya. Keadaan emosional merupakan satu reaksi kompleks yang berkaitan dengan kegiatan dan perubahanperubahan secara mendalam yang diikuti dengan perasaan kuat atau disertai dengan keadaan afektif, yang pada akhirnya keadaan emosional dapat tertuangkan dalam hal negatif seperti kesal, marah, atau tegang. (Makmun, 2002:14).

Dengan merujuk pada pemikiran James C. Coleman dalam Sukmadinata: (2007) di bawah ini dikemukakan beberapa 
cara untuk memelihara emosi yang konstruktif.

1. Bangkitkan rasa humor. Yang dimaksud rasa humor di sini adalah rasa senang, rasa gembira, rasa optimisme. Seseorang yang memiliki rasa humor tidak akan mudah putus asa, ia akan bisa tertawa meskipun sedang menghadapi kesulitan.

2. Peliharalah selalu emosi-emosi yang positif, jauhkanlah emosi negatif. Dengan selalu mengusahakan munculnya emosi positif maka sedikit sekali kemungkinan individu akan mengalami emosi negatif. Kalaupun ia menghayati emosi negatif, tetapi diusahakan yang intensitasnya rendah sehingga masih bernilai positif.

3. Senantiasa berorientasi kepada kenyataan. Kehidupan individu memiliki titik tolak dan sasaran yang akan dicapai. Agar tidak bersifat negatif, sebaiknya individu selalu bertolak dari kenyataan, apa yang dimiliki dan bisa dikerjakan, dan ditujukan kepada pencapaian sesuatu tujuan yang nyata juga.

4. Kurangi dan hilangkan emosi yang negatif. Apabila individu telah terlanjur menghadapi emosi yang negatif, segeralah berupaya untuk mengurangi dan menghilangkan emosi-emosi tersebut. Upaya tersebut dapat dilakukan melalui: pemahaman akan apa yang menimbulkan emosi tersebut, pengembangan pola-pola tindakan atau respons emosional, mengadakan pencurahan perasaan, dan pengikisan akan emosiemosi yang kuat.

Sama halnya dengan reaksi tindak tutur siswa, jawaban terhadap apa saja faktor yang menyebabkan siswa bertutur kata kotor jugalah bervariasi. Berdasarkan hasil wawancara, 252 responden sebagai pihak pertama/pembicara mengungkapkan faktor berbeda-beda. 169 dari 252 responden menyatakan kesal terhadap lawan bicaranya, 62 di antara 252 responden menyebutkan spontanitas, keceplosan, atau reflek sebagai faktor mereka bertutur kata-kata kotor. Selanjutnya, 59 responden dari keseluruhan mengatakan bercanda sebagai faktor. Selain itu, 51 dari mereka mengungkapkan marah dan 42 dari mereka menyebutkan emosi sebagai hal yang melatarbelakangi mereka bertutur kotor. Dari hasil wawancara ini, terdapat jawaban yang sangat mengejutkan, yakni dari 252 responden, 30 responden menyatakan bahwa mereka sudah terbiasa bekata-kata kotor. Selain dari faktor-faktor tersebut di atas, juga didapatkan pengaruh lingkungan, kejengkelan, badmood, membalas ejekan, habis kesabaran terhadap tingkah laku teman yang kurang menyenangkan, berontak, dan tersinggung 
menjadi faktor kenapa responden berkatakata kotor.

\section{Faktor Tindak Tutur Siswa}

Sama halnya dengan reaksi tindak tutur siswa, jawaban terhadap apa saja faktor yang menyebabkan siswa bertutur kata kotor jugalah bervariasi. Berdasarkan hasil wawancara, 252 responden sebagai pihak pertama/pembicara mengungkapkan faktor berbeda-beda. 169 dari 252 responden menyatakan kesal terhadap lawan bicaranya, 62 di antara 252 responden menyebutkan spontanitas, keceplosan, atau reflek sebagai faktor mereka bertutur kata-kata kotor. Selanjutnya, 59 responden dari keseluruhan mengatakan bercanda sebagai faktor. Selain itu, 51 dari mereka mengungkapkan marah dan 42 dari mereka menyebutkan emosi sebagai hal yang melatarbelakangi mereka bertutur kotor. Dari hasil wawancara ini, terdapat jawaban yang sangat mengejutkan, yakni dari 252 responden, 30 responden menyatakan bahwa mereka sudah terbiasa bekata-kata kotor. Selain dari faktor-faktor tersebut di atas, juga didapatkan pengaruh lingkungan, kejengkelan, badmood, membalas ejekan, habis kesabaran terhadap tingkah laku teman yang kurang menyenangkan, berontak, dan tersinggung menjadi faktor kenapa responden berkatakata kotor.
Berbicara mengenai faktor-faktor yang memengaruhi siswa bertindak tutur kotor, peneliti juga menjadikan responden sebagai pihak ketiga yang dapat menjadi informan. Hal ini berkenaan dengan faktor apa yang membuat teman-teman responden, di lingkungan mereka berada, bertindak tutur kotor. Dari hasil jawaban yang didapatkan, faktor yang disebutkan tidak terlalu berbeda dengan poin-poin yang ada di tabel 8. Hanya hasil persentase dan jumlah respondennya saja yang berbeda. Selain itu, ada beberapa responden yang menyatakan menjadi $\mathrm{ABG}$, gugup, kaget, gregetan, saling ejek, ikutikutan, frustasi, dan agar akrab terhadap teman menjadi faktor mengapa mereka bertindak tutur kotor.

Dari beberapa faktor di atas, dapat disampaikan beberapa point yang menarik perhatian, di antaranya, yaitu pengaruh lingkungan dan kebiasaan.

Dari pihak guru, faktor yang menyebabkan siswa berkata tutur tidak baik dilatarbelakangi oleh pergaulan dan mediamedia, seperti televisi dan internet. Selain itu, ketidakstabilan emosi seperti rasa marah atau sebal juga menjadi salah satu pemicu mereka berkata-kata kotor. Selanjutnya, lingkungan, baik lingkungan sosial maupun lingkungan keluarga juga mempunyai peran dalam membentuk etika komunikasi siswa. 
Pada suatu kasus terkadang orang tua memanggil anaknya dengan kata-kata yang kurang layak diucapkan, yang pada akhirnya tertransformasi dalam diri anak dan dipraktikkan dalam pergaulannya. Di sisi lain, kebiasan berkata kotor juga menjadi pemicu. Dengan kebiasaan tersebut siswa akan cenderung spontanitas dan bisa menjadi latah. Tidak heran jika pada akhirnya, berkata kotor ini bukanlah hal tabu dan tidak enak jika tidak diucapkan. Jelas kiranya dari faktor-faktor tersebut, diperlukan metode pendekatan karakter yang dapat diterapkan dalam diri siswa sehingga mereka menjadi insan yang utuh yang segala tidak dan tutur katanya terkontrol.

Lingkungan adalah segala sesuatu yang berada di sekitar kita, yang ada hubungannya dan berpengaruh terhadap diri kita. Dalam arti yang lebih spesifik, linkungan adalah hal-hal atau sesuatu yang berpengaruh terhadap perkembangan manusia dan lingkungan tempat manusia dapat saling berinteraksi disebut lingkungan sosial.

Lingkungan sosial merupakan lingkungan pergaulan antarmanusia, pergaulan antara pendidik dengan peserta didik serta orang-orang lainnya yang terlibat dalam interaksi pendidikan. Interaksi pendidikan dipengaruhi karakteristik pribadi dan corak pergaulan antarorang-orang yang terlibat dalam interaksi tersebut, baik pihak peserta didik (siswa) maupun para pendidik (guru) dan pihak lainnya. Tiap orang memiliki karakteristik pribadi masing-masing, sebagai individu maupun sebagai anggota kelompok. Karakteristik ini meliputi karakteristik fisik, seperti tinggi dan besar badan, nada suara, roman muka, gerak-gerik, dan karakterisik psikis seperti sifat sabar, pemarah (temperamen), sifat jujur, setia (watak), kemampuan psikomotor, seperti cekatan dan terampil (Sukmadinata, 2007:5).

Dengan adanya perbedaan di atas, adanya arahan dan pemahaman terhadap siswa akan lingkungannya mempunyai peran positif dalam mengenalkan terhadap bermacam-macam bentuk interaksi. Hasilnya, dengan adanya pemahaman dalam diri mereka maka mereka dapat mengantisipasi diri mereka ketika terjun dalam lingkungan. Antisipasi tersebut dapat berupa kemampuan mereka, misalnya, dalam mengontrol emosi mereka dalam berkomunikasi atau menciptakan komunikasi yang baik dalam lingkungannya.

Selanjutnya, hal yang perlu diperhatikan juga adalah karakteristik psikis para siswa. Karakter tempramen, misalnya, akan memengaruhi kemampuan siswa dalam menanggapi kesulitan-kesulitan baik dalam 
komunikasi maupun pembelajaran. Dengan demikian, jelas kiranya perlu penanaman karakter-karakter baik dalam jiwa siswasiswa sebagai generasi penerus. Karakterkarakter tersebut dapat menjadi fondasi kehidupan mereka kelak.

Berbicara tentang lingkungan yang dialami siswa SMA, selain lingkungan keluarga dan sekolah, siswa SMA juga mendapat pengaruh dan pendidikan dalam lingkungan masyarakat, yang merupakan lingkungan ketiga. Sebagai peserta didik sebenarnya mereka telah berada, hidup dan berkembang dalam lingkungan masyarakat, tetapi setelah selesai masa pendidikan, mereka masuk ke masyarakat dengan status yang lain. Hal ini menunjukkan tingkat kedewasaan dan kemandirian yang lebih tinggi. Dengan status sebagai anak, remaja ataupun orang dewasa, peserta didik mengalami proses pendidikan dalam lingkungan masyarakat. Oleh karena itu, siswa perlu diberikan arahan tentang hal-hal positif, khususnya dalam berkomunikasi, mengingat banyak sekali kata-kata yang kurang baik didengar telah tersebar dan menjadi hal biasa di kalangan sebuah masyarakat, Hal ini terbukti dengan munculnya kata-kata kotor yang disebutkan dalam tulisan ini. (Sukmadinata, 2007:5).
Salah satu cara yang dapat dilakukan untuk mengarahkan siswa sebagaimana pendapat di atas ialah dengan adanya pemberian motivasi. Motivasi sangatlah penting. Hal ini dapat terlihat misalnya pada contoh berikut. Apabila terdapat dua anak yang memiliki kemampuan sama dan memberikan peluang dan kondisi yang sama untuk mencapai tujuan, kinerja dan hasilhasil yang dicapai oleh anak yang termotivasi, akan lebih baik dibandingkan dengan anak yang tidak termotivasi.

Secara sederhana dapat dikatakan bahwa apabila anak tidak memiliki motivasi, dalam hal ini motivasi pembelajaran misalnya, tidak akan terjadi kegiatan belajar pada diri anak tersebut. Hal itu kadangkadang menjadi masalah karena motivasi bukanlah suatu kondisi. Apabila motivasi belajar anak itu rendah, umumnya diasumsikan bahwa prestasi siswa yang bersangkutan akan rendah. Pentingnya peranan motivasi dalam proses pembelajaran perlu dipahami oleh pendidik agar dapat melakukan berbagai bentuk tindakan atau bantuan kepada siswa. Motivasi belajar dirumuskan sebagai dorongan, baik diakibatkan faktor dari dalam maupun luar, untuk mencapai tujuan tertentu guna memenuhi atau memuaskan suatu kebutuhan. 
Selain lingkungan, hal yang menarik untuk dibahas dan dicari solusinya adalah tentang kebiasaan buruk (bad habit), yang dalam hal ini merupakan kebiasaan buruk bagi siswa dalam berkata-kata kotor yang akhirnya menjadi addiction (kecanduan). Addiction merupakan suatu hubungan emosional dengan suatu objek atau kejadian. Individu yang mengalami akan mencoba untuk menemukan kebutuhannnya terhadap intimasi. Addiction (pada tingkat yang paling dasar) adalah sebuah usaha untuk mengontrol dan memenuhi keinginan untuk mendapatkan kebahagiaan. (Waddington dan Smith, 2009:24).

Berdasarkan definisi di atas, dapat dikatakan bahwa sebenarnya kecanduan berkata-kata kotor tidak ada bedanya dengan minuman keras, rokok, narkoba, seks dan sebagainya. Berkata-kata kotor juga mengakibatkan kecanduan bagi para pembicaranya apabila tidak dikontrol. Akan tetapi, biasanya seseorang yang telah kecanduan tidak menyadari bahwa dirinya adalah seorang pecandu. Bahkan ia tidak mau disebut sebagai pecandu karena tidak menyadari bahwa perilaku tindak tuturnya yang kurang baik itu berlebihan.

Kasus-kasus yang dijumpai di lapangan bahwa banyak pelajar mengalami sindrom kata-kata kotor mengakibatkan mereka kurang nyaman jika tidak berkatakata kotor baik di dalam pembelajaran maupun di luar. Dengan demikian, tingkat penanganan sigap akan kasus-kasus tersebut perlu ditekankan agar tidak mengarah pada candu berat.

Menurut Horvart (1993:103-109) addiction adalah:

"An activity or substance we repeatedly carve to experience, andfor which we are willing if necessary to pay a price (or negative consequences)."

Berdasarkan defenisi di atas addiction berarti tidak hanya terhadap zat saja, tetapi juga terhadap aktivitas tertentu yang dilakukan secara berulang-ulang dan menimbulkan dampak negatif. Contoh kecanduan dapat bermacam-macam, di antaranya karena zat atau aktivitas tertentu seperti sexual activity, gambling, overspending, shoplifting, atau berkata-kata kotor.

Kay dan Tashman (2006:143-145) mengungkapkan addiction terdiri dari 3 tahapan. Ketiga tahapan tersebut yaitu:

1. Tahap pertama disebut dengan internal change (perubahan internal). Tahap ini ditandai dengan individu yang mulai menyadari perubahan mood yang dialaminya ketika individu tersebut terlibat dengan sumber addiction. Perasaan menjadi mudah marah, dan pada 
umumnya, menarik diri dan menjauhkan dirinya dari masalah-masalah dan perasaan yang tidak menyenangkan. Mulai tahap ini, individu mulai merasa addict dengan sumber addiction ketika merasakan stress. Individu akan menjauh dari orang lain dan mengalami pengalaman kecanduan.

2. Tahap kedua disebut dengan life style change (perubahan gaya hidup). Pada tahap ini, individu membangun kehidupannya di sekitar sumber addiction. Saat ini individu berapa pada tingkat tidak dapat mengontrol tingkah lakunya. Individu akan berupaya mengatur kehidupannya di sekitar sumber addiction. Ketika individu tersebut tidak berhubungan langsung dengan sumber addiction maka individu akan terusmenerus memikirkannya.

3. Tahap ketiga disebut dengan life breakdown (rusaknya kehidupan). Pada tahap ini, individu menganggap semua yang dilakukan benar, menurut dirinya. Tidak ada yang salah atau gagal. Individu menjadi sulit mengendalikan perasaannya dan sangat sulit berdiskusi mengenai masalah dalam kehidupannya.

Dari tiga tahap tersebut, tidak heran jika beberapa siswa sudah terbiasa berkata kotor dan sudah merasa nyaman dengan kata-kata tersebut. Hal ini disebabkan mereka sudah kecanduan berkata kotor. Dengan demikian, perlu diterapkan cara menghilangkan kebiasaan buruk dan addiction di kalangan mereka.

Pilpala menyatakan bahwa kebiasaan yang mengarah pada kecanduan adalah salah satu problema atau masalah yang dapat ditangani dengan menggunakan strategi pengelolaan diri. Hal ini dilakukan dalam suasana konseling kelompok agar remaja atau siswa yang mengalami permasalahan akan lebih mudah membicarakan permasalahan yang mereka hadapi bersamasama dengan anggota kelompok yang lain. Pada tahap kegiatan dalam konseling kelompok, konselor memberikan strategi pengelolan diri untuk mengatasi permasalahan yang dialami oleh remaja. Selanjutnya, remaja diharapkan mampu melaksanakan self-monitoring, stimulus control dan self-reward.

\section{DAFTAR RUJUKAN}

Aqib, Zainal dan Sujak. 2011. Panduan dan Aplikasi Pendidikan Karakter untuk: SD/MI, SMP/MTs, SMA/MA, $S M K / M A K$. Bandung: Yrama Widya.

Daradjat, Zakiah. 1998. Kesehatan Mental. Jakarta: CV Haji Mas Agung. 
Hovart, Arthur T. 1993. Psychology of Addictive Behaviors, Vol 7, Jun. hlm. 103-109.

Kay, J. Tashman, A., 2006, Essensials of Psychiatry. USA: John Wiley \& sons.

Koesoema, Doni A. 2010. Pendidikan Karakter: Strategi Mendidik Anak di Zaman Global. Jakarta: Gramedia.

Kusnaedi. 2013. Strategi dan Implementasi Pendidikan Karakter Panduan untuk Guru dan Orang Tua. Bekasi: Duta Media Tama.

Makmum, Abin Syamsudin. 2002. Psikologi Kependidikan Perangkat Sistem Pengajaran Modul.Bandung: Remaja Rosda Karya.

Qardawi, Yusuf. 1990. Al-Qur'an Menyuruh Kita Sabar, Terj. Aziz Salim Basyarahil. Jakarta: Gema Insani Press.

Prayitno dan Amti, Erman. 2004. DasarDasar Bimbingan dan Konseling. Jakarta: PT Rhineka Cipta.

Salam, Burhanuddin. 2000. Etika Individual Pola Dasar Filsafat Moral. Jakarta: PT Rineka Cipta.
Samani, Muchlas dan Hariyanto. 2011. Konsep dan Model Pendidikan Karakter. Bandung: PT Remaja Rosdakarya.

Schwartz, Merle J. 2008. Effective Character Education A Guidebook for Future Educators. New York: McGraw Hill

Shihab, M. Quraish. 2000. Tafsir AlMishbah. Ciputat, Penerbit Lentera Hati.

Surakhmad, Winarno. 1997. Psikologi Pemuda Bandung: Jenmars.

Sukmadinata, Nana Syaodih. 2007. Landasan Psikologi Proses Pendidikan. Jakarta: PT. Remaja Rosdakarya.

Waddington, Ivan dan Smith, Andy. 2009. An Introduction to Drugs in Sport: Addicted to Winning? London: Routledge.

Winkels, W.S. 1997. Bimbingan dan Konseling di Institusi Pendidikan. Jakarta: PT Grasindo 